\title{
Legislation and Practice Concerning Natural Disasters and Insurance in a Number of European Countries*
}

\author{
by C. Van Schoubroeck**
}

\section{Introduction}

In this contribution, we give a an overview of the way in which damage to goods ${ }^{1}$ caused by natural disasters is compensated by private insurance in a number of European countries. In so doing, a deliberate choice has been made. We opted, on purpose, for a horizontal analysis on the basis of a number of parameters rather than for a vertical analysis of the law and practice on a country by country basis. ${ }^{2}$ Given the great diversity of types of natural perils, the regulation and practice of compensating damage caused by them are essentially discussed from the point of view of the current situation in Belgium.

Until today, private insurance of natural disasters is not complusory in Belgium. In the absence of any specific legislation, the provisions of the Insurance Contracts Act of 25 th June, $1992^{3}$ have to be complied with when insuring the risk of natural disaster causing damage to goods. In addition, with regard to the so-called ordinary risks, the provisions of the Royal Decree of 24th December, 1992 regarding insurance against fire and other perils are applicable. ${ }^{4}$ In practice, however, private insurance of damage to goods caused by flood,

* This paper gives the main results of a research project carried out on the occasion of a conference organized by the Center for Risk and Insurance Studies in Leuven (Belgium) in 1994 about Natural Disasters and Insurance in Belgium". In order to ensure the accuracy and timeliness of the results, the information was collected by inquiring the competent control authorities, insurance companies and other interested organizations. The results have been update in September 1996, after contact with those who had cooperated in 1992. Apart from a few minor aspects, the situation in the countries concerned had not changed since the end of 1994.

** Post-doctorate researcher at the National Fund of Scientific Research, Belgium and member of the Center for Risk and Insurance Studies, Leuven.

${ }^{1}$ Bodily injuries caused by a natural disaster and compensation therefore by life or accident insurance are left out of consideration.

2 See, for a vertical overview of the law and practice in some European countries, e.g. CEA, Fire/ Theft Committee, "Natural Events", Report for Plenary Meeting, Paris, 30th-31st May, 1994, 8 pp. Verbond van Verzekeraars, Internationale vergelijking: dekking aardbeving en overstroming, 1993, 9 pp.

${ }^{3}$ Belgian Official Gazette, 20th August, 1992, amended by the Act of 16th March, 1994, Belgian Official Gazette, 4th May, 1994.

${ }^{4}$ Belgian Official Gazette, 31st December 1992; Article 1, § 1 and $\S 3$ Fire Royal Decree of 24th December, 1992 concerning fire (and other perils) insurance for so-called ordinary risks. 
earthquake and landslide is very exceptional or gives coverage only to a very limited extent. ${ }^{5}$ Nevertheless, the recent past (floods in the Valley of the Meuse and earthquakes with center in Roermond (Netherlands) end 1993-beginning 1994) has proven again that flood as well as earthquakes are also potential risks in Belgium which can cause significant damage. Given that it is assumed that such dangers are not normally covered under insurance policies, the damage caused by such dangers are at present compensated by the National Disaster Fund (Rampenfonds) by application of the Act of 12th July, 1976 concerning the reparation of damage caused to private goods by natural disasters. ${ }^{6}$ However, this is still state aid. By financial support of the government, a solidarity compensation is paid out. Moreover, compensation can only be granted for damage caused to private goods ${ }^{7}$ in accordance with block criteria. In addtion, there must be a government acknowledgment stipulating that a natural phenomenon of either an exceptional nature or a severity that cannot be anticipated and has caused serious damage, was involved. ${ }^{8}$

Keeping in mind this Belgian situation, ${ }^{9}$ we examine to what extent it is possible to compensate damage to property caused by flood, earthquake or landslide by private

5 See e.a. VAN NUFFEL, E., "Financiêle tegemoetkoming van de Staat bij naturrampen (algemene rampen) in België", in Natuurrampen en verzekering. Verslagboek Negende Leuvense Verzekeringsdagen, COUSY, H. \& CLAASSENS, H. (ed.), Antwerp, Maklu Uitgevers, 1995, 45-58; CLAASSENS, H., "Catastrofes in de branding: Hoe kwam het zover", The Insurance of Fire and Related Risks, Sure Symposium, Louvain, 3rd November, 1993, 10 pp.; ROUSSELLE, P., "Verzekering tegen aanslagen en natuurrampen. België", AIDA Colloquium, Ghent, 1986, Bulletin des Assurances, 1986 , 262-271.

${ }^{6}$ Belgian Official Gazette, 13th August, 1976; Article 4 (4), Act of 12th July, 1974.

7 The listing of such private property in Article 3.A, Act of 12th July, 1976, for the most part accords with the term ordinary risks in Article 5 of the Royal Decree of 24th December, 1992 concerning the implementation of Articles 30,31, 44, 52, 67 and 70 of the National Insurance Contracts Act of 25th June, 1992, Belgian Official Gazette, 31st December, 1992 and Article 1, § 1 Fire Royal Decree of 24th December, 1992.

8 Article 2, Act of 12th July, 1976.

${ }^{9}$ In August 1992 the Belgian government consulted the Commission of Insurance (advisory commission in which all parties involved in insurance business are represented) on the question of whether the risks which were compensated by the Act of 12th July 1976 could be insured by private insurance. In 1993 the majority of private insurers in Belgium has made a proposal concerning a partial insurance of the damage caused by earthquake. In the beginning of 1995 they formulated a new proposal for the insurance of damage caused to goods (less than BEF 30 million) by flood and earthquake (BVVOCASO proposal). See BOON, J., "Propositions des assureurs pour l'assurance des catastrophes naturelles en Belgique", in Natuurrampen en verzekering. Verslagboek Negende Leuvense Verzekeringsdagen, COUSY, H. \& CLAASSENS, H. (ed.), Antwerp, Maklu Uitgevers, 1995, 159-169. This proposal was amended during the course of 1995-1996 into a proposal for the insurance of a package of flood, earthquake, landslide and storm. This proposal is now subject to consultation between the private insurers and the authorities. 
insurance in other European countries. ${ }^{10}$ In the first part, we give an overview of the specific legislative rules on private insurance for the foregoing risks and of such insurance policies that exist, even in the absence of such rules (2.). Thereafter, we look at the various manners in which the insurance is offered (3.). Finally, we give some thought to the question of whether the systems of private insurance which have been described, correspond to either a traditional insurance or either a de facto solidarity compensation paid out by an insurer instead of the government (4.).

\section{Specific legal rules?}

A. Existing legal rules

1. Overview: legal rules on flood, earthquake and landslide

\begin{tabular}{|c|c|c|c|c|}
\hline & Flood & Earthquake & Landslide & Rules \\
\hline France & + & + & + & Act of 1982 \\
\hline Norway & + & + & + & Act of 1989 (since 1980) \\
\hline $\begin{array}{l}\text { Spain: } \\
\text { Consortium } \\
\text { private insurers }\end{array}$ & $\begin{array}{l}+ \\
+\end{array}$ & $\begin{array}{l}+ \\
+\end{array}$ & $\overline{-}$ & $\begin{array}{l}\text { Act of 1990/Royal Decree } 1986 \\
\text { (since 1954) }\end{array}$ \\
\hline $\begin{array}{l}\text { Switzerland: } \\
\text { Private insurers } \\
\text { Cantonal insurers }\end{array}$ & $\begin{array}{l}+ \\
+ \\
+\end{array}$ & - & $\begin{array}{l}+ \\
+ \\
+\end{array}$ & $\begin{array}{l}\text { Act of } 1990 / \text { Order of } 1990 \\
\text { (practice since 1950) }\end{array}$ \\
\hline Denmark & sea flooding & - & - & Act of 1991 \\
\hline $\begin{array}{l}\text { Germany } \\
\text { Baden-Württemberg until } \\
\text { 1st July, } 1994\end{array}$ & + & + & $?$ & \\
\hline
\end{tabular}

+ rules exist $\quad-$ rules do not exist ? missing data

10 This contribution focuses in particular on the situation in European countries, other than France and the Netherlands. The law and practice in these countries has already been quite extensively described by other authors.

See for France e.g., MAGNAN, S., "L'assurance comme technique d'indemnisation des catastrophes naturelles en France", in Natuurrampen en verzekering. Verslagboek Negende Leuvense Verzekeringsdagen, COUSY, H. \& CLAASSENS, H. (ed.), Antwerp, Maklu Uitgevers, 1995, 121-132; CRESCENZO-D'AURIAC, M. B., Les risques catastrophiques. Evénements naturels, politiques et technologiques, Paris, Argus, 1988, 377 pp.; CRESCENZO-D'AURIAC, M. B., "Le régime d'indemnisation des catastrophes naturelles (loi du 13 juillet 1982) à l'épreuve du temps", R.G.A.T., 1988, 445-467; BARROIS, H., "Catastrophes naturelles", Juris Classeur Civil, Annexe, Fasc. 25, 1994, 4-20.

See for the Netherlands, e.g. RENGER, F., "Verzekering en natuurrampen in Nederland", Natuurrampen en verzekering. Verslagboek Negende Leuvense Verzekeringsdagen, COUSY, H. \& CLAASSENS, H. (ed.), Antwerp, Maklu Uitgevers, 1995, 133-148; Sir LEON BRITTAN, combined answer on behalf of the Commission to written questions no. 1392/92, no. 1394/92 and no. 1438/92, O.J. C58, 1st March, 1993, 18-19; KABEL, P., "Aardbevings- en overstromingsperikelen: Frans antwoord op Nederlands probleem?", AssurantieMagazine, 17th March, 1994, 31; X, "Jaarvergadering Verbond: door klimaatsveranderingen krijgen verzekeraars te maken met andere risico's", Het Verbond, 7th July, 1994; X, "Nieuwe minister wil impasse doorbreken over verzekering tegen natuurschade", VerzekeringsMagazine, 7th September, 1994; Floods in The Netherlands, December 1993, Lower House, Session year 1993. 1994, 23 564; Statement of the assessment of expenditure and receipts under title VII (Ministry of Internal Affairs) for the year 1994, Lower House, Session year 1993-1994, 23 400 VII, no. 34. 


\section{Clarification}

The overview of legal rules concerning the private insurance of natural disasters that currently exist in a number of European countries shows that, apart from France, there are separate and specific rules in another four countries for the private insurance of damage caused by one or more of the relevant perils of flood, earthquake or landslide.

2.1. Before briefly clarifying this overview, it must be noted that the rules referred to principally concern so-called general disasters. On the other hand, compensation for so-called agricultural disasters like damage to crops and land and damage to forest, is often regulated in a different way. For example, in Finland and Greece, there are no specific legal rules for so-called general disasters but there are specific rules for agricultural disasters. ${ }^{11}$ In Norway, harvest and forestry damage may be excluded from insurance contracts but can be compensated by the National Natural Perils Fund (Staten Naturskadefond). ${ }^{12}$ In Denmark as well, the Act on the compensation of Sea Flood excludes damage to land. ${ }^{13}$ Likewise, in Spain agricultural risks (land and animal) are not governed by the Act 21/1990 of 19 September 1990 and the Royal Decree 2022/1986 of 29 August. ${ }^{14}$

2.2. The Norwegian and Spanish rules are applicable to the insurance of several natural disasters, including the three perils concerned here. These regulations define the insurance conditions rather extensively.

In Norway, the insurance of damage by inter alia landslide, flood, tempest, storm, inundation, earthquake and volcanic eruption is currently governed by the Insurance Contracts Act of 16th June, 1989, and the Natural Perils Act of 16th June, 1989.15

The Spanish Act 21/1990 of 19th September, 1990, and the Royal Decree 2022/1986 of 29 th August, $1986^{16}$ apply basicly to compensation paid out by the public insurer "Consorcio

11 In Finland, state aid is given to farmers for damage to crops caused by the weather. In Greece, the insurance of agricultural damage is governed by Act no. 1790/1988. infra.

${ }^{12}$ Act on Insurance against Natural Perils and Insurance Contracts Act of 16th June, 1989: see

13 Article 2 (5), Act of 6th June, 1991.

14 "Le "Consorcio de Compensación de Seguros" et la couverture des risques catastrophiques en Espagne", Consorcio de Compensación de Seguros, Madrid, 16 (Le "Consorcio").

15 In Norway, since 1918 there has been a limited possibility to take out insurance against disasters such as landslide, inundation, storm and tempest. The present system has been in effect since 1st January, 1980 and was brought in as a consequence of the amendment of the Act on Natural Perils (introducing the Norwegian National Perils Fund ("Statens Naturskadefond")) and the Insurance Contracts Act, both on 8th June, 1979. See, with regard to the earlier legislation, NORSK NATURSKADEPOOL, Insurance against natural perils in Norway 5th May, 1994, 6 pp.

${ }^{16}$ Ley 21/1990, del 19 de septembre, para adaptar el derecho Español a la directiva 88/357/CEE, por la que se aprueba el estatuto legal del consorcio de compensación de seguros; Real Decreto 2022/ 1986, del 29 de agosto, por el que se aprueba el reglamento de riesgos extraordinarios sobre las personas y los bienes; Orden del 28 de noviembre de 1986, por la que se desarrolla el Real Decreto 2022/ 1986, del 29 de agosto, aprobando el Reglamento de riesgos extraordinarios sobre las personas y los bienes. See, concerning the earlier legislation with regard to the Consorcio de Compensación de Seguros since the Act of the 16th December, 1954, Le "Consorcio", 7-12; Introductory considerations, Real Decreto 2022/1986. 
de Compensación de Seguros". ${ }^{17}$ Nevertheless, these provisions are to be regarded as minimum conditions to which each insured is entitled, if the coverage would be offered by a private insurer. ${ }^{18}$ The Consortium covers the damage that has been caused by the following perils: earthquake, tidal wave, flooding, volcanic eruption, cyclone and landslide caused by flooding. ${ }^{19}$ However, compensation may only be granted upon the condition that this risk is not explicitly and specifically guaranteed under the insurance policy or that the private insurer that ought to guarantee the risk is not solvent. ${ }^{20}$

2.3. On the contrary, the specific legal measures existing in Denmark and Switzerland are limited to the private insurance of specific disasters. The Danish Flood Damage (Compensation) Act of 6th June, 1991, only covers compensation for damages as a consequence of "flood meaning an inundation resulting from an extremely high water level of the sea caused by storm". ${ }^{21}$

The Swiss Act of 20th March, 1992, and the Bundesrat Decree of 18th November, 1992, govern the compulsory extension of fire coverage in all fire insurance contracts for buildings and contents, to the risk of damage to property by flood and landslide. ${ }^{22}$

2.4. An important hallmark of the aforementioned national legislation is its "territorial tie". ${ }^{23}$ This means that the provisions thereof are applicable to all policies providing coverage for damage to property situated in the country in question, regardless of the location of the head office of the insurer offering the said policy. ${ }^{24}$

\section{B. Absence of a specific regulation}

Is was apparent from the analysis that, even in the absence of any specific regulation, in most European countries the danger of flood, earthquake and landslide can be, and indeed is commonly, insured. In several countries the above mentioned dangers have often been, for many years, covered by limited technical insurance policies such as motor hull

${ }^{17}$ See infra, 3., B. 2.2., d.

${ }^{18}$ Article 8, Act 21/1990; Le "Consorcio", 12; 19.

${ }^{19}$ Article 6, 1, a; Article 6, 2 Act 21/1990; Article 1 and Article 2, Royal Decree 2022/1986.

${ }^{20}$ Article 8, Act 21/19910; Le "Consorcio", 12. The Consorcio acts in such circumstances as a guarantee fund. In case the basic policy includes some of these risks, the Consorcio will coverage only the rest. ${ }^{21}$ Article 1 (2), Act of 6th June, 1991.

${ }^{22}$ Article 38a, Bundesgesetz über die Direktversicherung mit ausnahme der Lebensversicherung

of 20th March, 1992, and Verordnung über die Elementarschadeversicherung of 18th November, 1992, as amended on 11th January, 1996 (Bundesrat Decree). These rules are in fact the legislative embodiment of a practice that had already existed since the beginning of the fifties.

${ }^{23}$ Spain: Le "Consorcio", 16; Denmark: Article 7 (3) and Article 8 (1), Act of 6th June 1991; Switzerland Article 38a, Act of 20th March, 1992; Article 1, Bundesrat Decree of 18th November, 1992; Article 3, Contract of the Swiss Elementarschäden-Pool of 26th January, 1990; Norway: Clause 2.3, Industrial Insurance Terms, March 1994.

24 This territorial tie raises important questions of Community insurance law. For example, which by the law is applicable to the insurance contract, which provisions could be regarded as provisions justified general good, how organizing the participation in guarantee funds and financial supervision by the Member State in which the insurer's head office is situated, see CLAASSENS, H., "Quelques aspects de droit européen concernant l'assurance des catastrophes naturelles", in Natuurrampen en verzekering. Verslagboek Negende Leuvense Verzekeringsdagen, COUSY, H. \& CLAASSENS, H. (ed.), Antwerp, Maklu Uitgevers, 1995, 217-227. 
insurance (flood in Denmark, Belgium, the Netherlands; earthquakes in Greece, Norway and Portugal, the Netherlands and Belgium), boat insurance (flood in Denmark), electrical appliances or machinery insurance (earthquake in Greece; earthquake and flood in Norway), industrial all-risk insurance (flood in Denmark; earthquake, flood and landslide in Norway). ${ }^{25}$ Furthermore, a random sample shows that on the Belgian market as well, motor hull insurance offers general coverage for damage caused by flood and reasonably general coverage for earthquake hazards similarly, in the Netherlands, there is general coverage for damage to cars caused by earthquake and flood. ${ }^{26}$ It is interesting to note that these policies are never mentioned in discussions about the insurance of national disasters. The discussion focuses instead on insurance policies in which an enterity of buildings and contents, separate or together, is insured. Therefore, the research has been limited to this last type of insurance contracts.

1. Overview: Coverage available and at least reasonably widespread, in absence of legal rules

\begin{tabular}{|c|c|c|c|c|c|c|c|c|c|}
\hline \multirow[b]{2}{*}{ Risk } & \multicolumn{3}{|c|}{ Flood } & \multicolumn{3}{|c|}{ Earthquake } & \multicolumn{3}{|c|}{ Landslide } \\
\hline & private & $\begin{array}{l}\text { com- } \\
\text { merc. }\end{array}$ & indust. & private & $\begin{array}{l}\text { com } \\
\text { mer }\end{array}$ & indust. & private & $\begin{array}{l}\text { com- } \\
\text { merc. }\end{array}$ & indust. \\
\hline $\begin{array}{l}\text { U.K. } \\
\text { Portugal } \\
\text { Greece } \\
\text { Italy } \\
\text { Germany }\end{array}$ & $\begin{array}{l}\text { stand. } \\
\text { stand. } \\
+ \\
+ \\
+\end{array}$ & $\begin{array}{l}+ \\
\text { stand. } \\
+ \\
+ \\
+\end{array}$ & $\begin{array}{l}+ \\
\text { stand. } \\
+ \\
+ \\
+\end{array}$ & $\begin{array}{l}\text { stand. } \\
+ \\
+ \\
+ \\
+\end{array}$ & $\begin{array}{l}+ \\
+ \\
+ \\
+ \\
+\end{array}$ & $\begin{array}{l}+ \\
+ \\
+ \\
+ \\
+\end{array}$ & $\begin{array}{l}\text { stand. } \\
+ \\
+ \\
+ \\
+\end{array}$ & $\begin{array}{l}+ \\
+ \\
+ \\
+ \\
+\end{array}$ & $\begin{array}{l}+ \\
+ \\
+ \\
+ \\
+\end{array}$ \\
\hline $\begin{array}{l}\text { Denmark } \\
\text { Austria } \\
\text { Finland } \\
\text { Sweden } \\
\text { Luxemburg }\end{array}$ & $\begin{array}{l}- \\
- \\
- \\
+\end{array}$ & $\begin{array}{l}+ \\
- \\
- \\
? \\
?\end{array}$ & $\begin{array}{l}+ \\
- \\
- \\
? \\
?\end{array}$ & $\begin{array}{l}- \\
- \\
+ \\
+\end{array}$ & $\begin{array}{l}- \\
- \\
- \\
? \\
?\end{array}$ & $\begin{array}{l}- \\
- \\
\bar{?} \\
?\end{array}$ & $\begin{array}{l}- \\
- \\
- \\
+ \\
-\end{array}$ & $\begin{array}{l}- \\
- \\
\bar{?} \\
?\end{array}$ & $\begin{array}{l}- \\
- \\
? \\
?\end{array}$ \\
\hline Switzerland & & & & & $\begin{array}{r}\mathrm{pc} \\
\mathrm{dec}\end{array}$ & & & & \\
\hline $\begin{array}{l}\text { Belgium } \\
\text { Netherlands }\end{array}$ & excepti & onally & & - & $\operatorname{lin}$ & & - & $?$ & \\
\hline
\end{tabular}

+ coverage available in principle and at least reasonably wide-spread

- coverage not available or not reasonably wide-spread

? missing data

${ }^{25}$ Danish Insurance Association, letter of 24th August, 1994; Greece, Viggas Reinsurance Brokers, fax of 30th September, 1994; Norsk Naturskadepool, op. cit., 2; Portugal, via the reinsurer Secura, fax of 3rd October, 1994.

${ }^{26}$ Even following the flood in the Netherlands in 1993, this coverage presented no problems. In total, the (estimated) costs resulting from this disaster, for motors insurers is supposed to have been less than 1 million guilders: see letter from the Verbond van Verzekeraars to the members of the motor vehicle department concerning the inquiry relating to salvage costs/damage treatment for cars in (flooded areas), dated 25th January, 1994. 


\section{Clarification}

This table gives an overview of the risks that, in the European countries where there are no specific set of rules, are in principle insurable and are at least reasonably generally covered under other than all-risk insurance policies. ${ }^{27}$

2.1. On the basis of this table, it appears that the private insurance of damage caused by flood and earthquake is at least reasonably wide-spread in the U.K., Portugal, Greece and Germany. Furthermore, in the U.K., the insurance of such risks is standard market practice and insured without additional premiums in all policies covering private risks (domestic household policies). In Portugal, damage caused by flood is also standard market practice. As a consequence of decisions issued in the past, compensation of damages caused by earthquakes continues to be generally covered in Portugal for commercial and industrial risks, and somewhat less for private risks. ${ }^{28}$ In Germany, the importance of the insurance of national disasters is slowly on the increase. ${ }^{29} \mathrm{In}$ accordance with the recommendations of the Verband der Sachversicherer, a package of six national disasters is insured together (see below, C. A. 2. d.), pursuant to the provisions of the Besondere Bedingungen issued by the Verband der Sachversicherer. ${ }^{30}$ These Bedingungen provide a descriptive definition of the dangers of flood, earthquake, subsidence, landslide, snow drift and avalanche. ${ }^{31}$

\footnotetext{
27 We would make a reservation concerning the hazard of landslide, because the data in this respect were not always explicitly available.

${ }^{28}$ Earthquake damage was previously covered generally and free of charge in all policies. Although, from 1993, the Portuguese insurance companies have been obliged by reinsurers to ask for a small additional premium for earthquake hazard, many insurers bore this additional premium themselves vis-à-vis the reinsurers. At the end of 1993, and formalized in a convention between the most important Portuguese insurers, it was agreed as from 1994 to actually charge an additional premium and post it to a separate account. In addition, all fire policyholders were informed that, unless they indicated the contrary, earthquake coverage would be excluded upon renewal of the policy. This measure met with reasonable success in the case of private risks but not in the case of industrial risks. See information obtained via the reinsurer Secura, September 1994.

29 Until August 1991, damage from national disasters was only covered in Baden-Württemberg by the Pflicht- und Monopolanstalten, whereby such damage was mandatory included in compulsory fire insurance policies. These Monopolanstalten had to be abolished at the latest by 1st July, 1994, pursuant to Article 2, 2 and Article 3 of the third non-life insurance directive of 18th June, 1992, Article 4 of the first non-life insurance directive of 24 th July, 1973, and Article 12, 2 of the second non-life insurance directive of 22nd June, 1988.

The Bundesaufsichtsamt für das Versicherungswesen has given the German market approval for the insurance of "Elementarschäden".

${ }^{30}$ Besondere Bedingungen für die Versicherung weiterer Elementarschäden in der Wohngebäudeversicherung $(\mathrm{BEW})$; Besondere Bedingungen für die Versicherung weiterer Elementarschäden in der Hausratversicherung (BEH); Besondere Bedingungen für die Versicherung weiterer Elementarschäden bei gewerblichen Risiken (BEG). See e.g. Federal Supervisory Authority, Business Report 1995, Berlin, 43-45.

31 "Die BEH, BEG und BEW sind vom Bundesaufsichtsamt für das Versicherungswesen den meisten Mitgliedsunternehmen zur geschäftsplanmässigen Verwendung genehmigt worden. Ab 1/7/1997 steht es jedoch den Unternehmen wegen Wegfalls der Genehmigungspflicht von AVB und Klauseln frei, Änderungen dieser seinerzeit vom Verband unverbindlich empfohlenen AVB vorzunehmen", Verband der Sachversicherer, fax of 28th October, 1994.
} 
2.2. In Italy, coverage for flood and earthquake is reasonably widespread for industrial and commercial risks and is becoming increasingly important. Although it is possible to get insurance coverage for private risks, this rarely occurs in practice. ${ }^{32}$

2.3. In Finland and Luxemburg, in principle, there is no coverage for the natural catastrophes in question. To explain this, it is stated that the risk is too small. In Denmark, the fire policy can provide a very limited coverage for fresh water flooding. On Austria, we got information from one insurer. He covers damage to buildings and household furnishings by flood and earthquake. In general however, these risks are not insured. ${ }^{33}$

2.4. Finally, it is to be noted that in Switzerland earthquake damage is not insured. ${ }^{34}$ Nevertheless, compensation can be obtained. The private insurers who insure buildings situated in the cantons of Obwalden, Geneva, Uri, Schwyz, Ticino, Appenzell IR, Wallis, the Principality of Liechtenstein and the enclaves of Büsingen and Campione against fire and who member of the Schweizerischer Sachversicherungsverband, are also affiliated with the Interessengemeinschaft zur Übernahme von Erdbebenschäden. This latest Earthquake Pool can decide to pay out limited compensation for damage to buildings that are insured with the members. The insured himself must not pay any additional premium. ${ }^{35}$ For buildings situated in the other 19 cantons, compensation for damage to buildings caused by earthquakes can be obtained from the Schweizerische Pool für Erbebenversicherung. This pool of cantonal monopoly insurers provides coverage similar to that provided by the Earthquake Pool (see infra).

\section{Conclusion}

From the foregoing data, it appears first that the private insurance of damage to goods by the national perils of flood, earthquake and probably also landslide, is generally available in Europe. Moreover, it should be noted that European countries take a different position towards the different types of national disasters. In countries where there is little danger of earthquakes, it is not insured (e.g. Finland and Denmark) or is included as standard (e.g. domestic household insurance contracts in the U.K.). On the other hand, in countries where there is a serious danger of earthquakes, this danger is either not insured (e.g. Italy for private goods or The Netherlands) or is relatively well covered (e.g. Greece). Furthermore, an interesting feature is that the coverage of the national disasters under discussion is not limited as a whole to private goods. Coverage is offered, sometimes predominantly, in insurance contracts concerning commercial as well as industrial risks. As a result, it can be concluded that the insurability of flood, earthquake and landslide is no longer an issue of discussion.

\footnotetext{
32 Nor is it possible to call on state aid in cases of natural disaster in Italy. Apparently, a debate is going on about the question of organizing a national pool. See also GAVERBI, D., "Catastrophes naturelles: le projet de loi à l'étude en Italie", Geneva Papers on Risk and Insurance, 1993, 454-465.

33 Verband der Versicherungsunternehmen Österreichs, fax of 8th September, 1996.

${ }^{34}$ Since the beginning of 1994 , a limited coverage for earthquake damage to buildings and contents has been offered in connection with the fire policy. This insurance is however not important and not widespread, AXCO Insurance Intelligence Services, Survey Report on Switzerland, May 1995, 71.

35 A percentage of the total premium is nonetheless earmarked for the Earthquake Pool.
} 
The core problem that is currently on the agenda is of a twofold nature. First, there is the question of the way the insurance against natural disasters is offered (3.). Second, the question whether the systems of private insurance which have been described above, correspond to either a traditional insurance or a de facto solidarity compensation paid out by an insurer instead of the government (4.)?

\section{The way the insurance is offered}

An important characteristic of the laws and practice in the different European countries is that none of the systems of compensation of damage caused by natural disasters is identical. They have nevertheless a number of features in common, which will be described hereafter. It should be recalled that the aforementioned all-risks policies (2.B.) are not taken into account in this analysis.

\section{A. (Compulsory) extension of the scope of the coverage}

1. Compulsory insurance

First of all, it is clear that no European country requires protection against damage caused by natural disasters by means of insurance. Insurance for natural disasters is nowhere compulsory. Moreover, nowhere on the market is a "natural catastrophe" 36 , "earthquake", or "flood" policy offered.

Secondly, natural disasters can usually be covered in either multirisk insurance contracts covering damage to goods, or only in a fire insurance contract, but generally as an extension of the fire coverage. In many countries, this extension is compulsory, in as far as no other coverage exists. In other countries, it is general practice. It is essential that, notwithstanding the legal obligation or common practice of this extension of the fire coverage, no European country has made the fire insurances or other of these so-called basic insurances compulsory. ${ }^{37}$

2. Relationship between the basic insurance and coverage for natural disasters

In the relationship between basic insurance and coverage for flood, earthquake and landslide, we can overall differentiate four formulae. The application of a formula can vary, depending on the nature of the risk to be insured.

\subsection{Automatic coverage}

The formula of "automatic coverage" incorporates the feature that the fire insurance contract or any other insurance contract covering damage to goods, gives automatically coverage against damage caused by one or more natural perils, even if this coverage is not expressly described in the policy. This formula is provided for in Article 7 of the Spanish Act $21 / 1990$.

\footnotetext{
36 An exception to this rule are the policies for very large industrial risks in, inter alia, Italy.
}

37 An exception to this rule applies for the Monopolanstalten in Baden-Württemberg up until 1st July, 1994, and still in Switzerland for the Monopolanstalten in the 19 cantons. Here, fire insurance policies for buildings are compulsory and coverage for contents is also compulsory in certain Cantons, see Axco Insurance Intelligence Services, Survey Report on Switzerland, May 1995, 59. 
Wherever a private insurer issues a fire and related risks policy, or a policy for theft, mechanical breakdown or water damage for goods ${ }^{38}$ situated in Spain ${ }^{39}$ and does not explicitly and specifically underwrite the risks of flood, earthquake or landslide, such goods are directly insured with the Consortium.

A similar automatic link formula exists in Switzerland for earthquake risks. If a building situated in one of the aforementioned 7 cantons, Liechstenstein or the enclaves of Büsingen and Campione, is insured against fire by a member of the Earthquake Pool, compensation can be obtained for earthquake damage. ${ }^{40}$ By contrast with the Spanish system, payments here are voluntary: "ein klagbarer Anspruch besteht nicht". ${ }^{41}$

\subsection{Statutory compulsory extension of the scope of the coverage}

The second formula includes the laws imposing an obligation to extend the scope of the coverage to the risk of natural disasters, in as far as no other coverage exists. ${ }^{42}$

Most national legislation provides that the insurance policy concerning fire risks must extend the insurance to the compensation of damage by one or more of the natural disasters concerned here. This formula applies in Norway for the danger of flood, earthquake and landslide,$^{43}$ in Switzerland for flood and landslide ${ }^{44}$ and in Denmark for the danger of sea flooding. ${ }^{45}$ In a number of other countries, not only fire insurance policy but all policies insuring goods against damage caused by e.g. theft, water or mechanical breakdown must obligatory contain coverage against damage by such natural catastrophes. We meet this formula in France. In France, the fire insurance contract as well as any other insurance contract covering damage to goods, compulsory extent the coverage against damage caused by natural disasters, upon the condition that the damage has been officially recognized by the government as a disaster.

Once again, a major problem concerning the application of the European Insurance Law as set down in the second and third non-life insurance directives of 22nd June, 1988, and 18th June, 1992 and in the European Economic Area agreement of 2nd May, 1992 arises. Can the statutory obligatory extension of the scope of the coverage be regarded as compulsory insurance within the meaning of the European Directive consequently, the special provisions concerning the law applicable to the insurance contract (Article 7 and 8 of the second non-life insurance directive) and concerning systematic communication of insurance conditions, documents and tariffs (Article 30, 2 of the third non-life insurance directive) are applicable.

38 See, for excluded goods, Article 6, 2, Act 21/1990.

39 Article 6, 1, Act 21/1990.

40 Under condition that the building is not insured against earthquake, Article 2.2, Reglement für die Vergütung von Erbebenschäden.

41 Article 2, Statut Interessengemeinschaft zur Übernahme von Erdbebenschäden; Article 1.1, Reglement für die Vergütung von Erbebenschäden.

42 E.g. in Norway and Article 2, Danish Act of 6th June, 1991.

43 Statutory provisions introduced by amendment dated 8th June, 1979 to the Insurance Contracts Act, Norsk Naturskadepool, Insurance against natural perils in Norway, 5th May, 1994,2.

44 Article 38a, Act of 20th March, 1992; Article 1, Bundesrat Decree of 18th November, 1992.

45 Article 2, Act of 6th June, 1991. 


\subsection{De facto compulsory extension of the scope of the coverage}

The formula of de facto compulsory extension of the scope of the coverage means that for natural disasters it is linked up with the underwriting of a fire coverage. This formula is standard market practice in Greece, Portugal, Italy and the U.K., ${ }^{46}$ both for flood and for earthquake risks. In the U.K., it is also general practice to link the coverage against flood to the storm coverage. ${ }^{47}$ The aforementioned Austrian insurer also covers the risks of flood and earthquake as an extension of the storm coverage for buildings.

\subsection{Package insurance}

With this fourth formula, damage caused by natural disasters is insured only as a package of certain natural disasters. It would appear that this formula is only applied in Germany. The danger of flood, earthquake, landsubsidence, landslide, snowpressure and avalanche described in the Besondere Bedingungen ${ }^{48}$, can only be insured as a package under property damage insurance (Hausrat, Wohngebäude, Gewerbe, Landwirtschaft). ${ }^{49}$

\section{$B$. The various systems of insurance against natural disasters}

\section{Self-insurance and self-insurance with government support}

The research learns that in Europe three major systems of insurance of natural disasters exist. The first two systems are of less interest to us here. These are self-insurance ${ }^{50}$ and selfinsurance coupled with governmental support. The latter approach is followed in Belgium (Act of 12 July, 1976 concerning the reparation of damage to private goods caused by natural disasters), in Norway where the National Natural Perils Fund pays a solidarity compensation, ${ }^{51}$ and in the Netherlands where the state aid is organized after a disaster has occurred. ${ }^{52}$

It is interesting to note that the Norwegian National Natural Perils Fund, unlike the Belgian Catastrophe Fund, will not compensate if the damage is covered by insurance or if it had been possible to take out insurance against the damage by means of ordinary and

${ }^{46}$ See the Recommended Standard Fire and Special Perils policy wordings for commercial and industrial risks issued by the Association of British Insurers, May, 1991.

${ }^{47}$ Association of British Insurers, letter of 7th April, 1994.

${ }^{48}$ Besondere Bedingungen für die Versicherung weiterer Elementarschäden in der Wohngebäudeversicherung (BEW); Besondere Bedingungen für die Versicherung weiterer Elementarschäden in der Hausratversicherung $(\mathrm{BEH})$; Besondere Bedingungen für die Versicherung weiterer Elementarschäden bei gewerblichen Risiken (BEG).

${ }^{49}$ ROSING, J., "Deckung von Elementarschäden", Der Versicherungskaufmann, 1994/3, 10.

${ }^{50}$ In Switzerland private funds, such as the Fonds suisse de secours pour dommages non assurables causés par des forces naturelles, offer some help in case of a natural disaster.

51 The maximum compensation amounting to NOK 405.000, see Norwegian Pool of Natural Perils, fax of 6th September 1996.

52 In Switzerland state aid can be provided by the cantons or by the confederation. Federal law does not prescribe general system, but there are scattered dispositions e.g. in the law about rivers and lakes. In case of particular heavy losses, the Confederation has granted to the Cantons and other public entities an additional and exceptional help, see letter of 26th August 1994 Federal Office of Private Insurance. 
common types of insurance. ${ }^{53}$ Given the statutory obligation to extend fire coverage to natural disasters, the National Natural Perils Fund need only be involved in compensating damage to goods that are excluded from coverage pursuant to the law. ${ }^{54}$ In fact, the system of self-insurance and governmental support also exists in the Netherlands. However, the difference with the Belgian and Norwegian system lies in the absence of any statutory structure and the fact that governmental support is organized after the disaster has occurred. ${ }^{55}$

Finally, it should also be mentioned here that the Spanish public insurer Consorcio, is discharged from its obligations where the government declares a certain event to be a national disaster, a "Calamidad Nacional". ${ }^{56}$

\section{Premium collection before the event}

Besides both aforementioned systems, only the basic system of insurance (by private or public insurer) on the basis of ex ante premium collection is used. The characteristic of this system is that the premium is collected at the time of subscription of the policy before any disaster has occurred. Broadly speaking, this basic system of insurance on the basis of ex ante premium collection occurs in several forms.

\subsection{Overview}

a) Individual private insurer $\rightarrow \quad$ reinsurance, private or public

b) Individual private insurer $\rightarrow$ pool $\rightarrow \quad$ reinsurance

c) Individual private insurer $\rightarrow$ pool $\rightarrow$ reinsurance $\rightarrow$ State guarantee $\rightarrow$ additional ex post premium

d) Individual private insurer $\rightarrow$ public insurer $\rightarrow$ State guarantee

\subsection{Clarification}

\section{a. First variant}

The most frequent variety is whereby the individual insurer offers the coverage, collects the premium and reinsures the risk on the private reinsurance market. In France, the private insurer can reinsure the risk with a reinsurer who works under a State guarantee. The insurer has the possibility to reinsure the policy at the "Caisse Centrale de Réassurance", a reinsurer operating under state guarantee.

Should this private insurer be a mutual insurance association, then it is possible that, following a claim, it will ask for a supplementary ex post premium. In this case, the system of ex ante premium collection is coupled with an additional ex post premium. However, I did not get any information whether there are mutual insurance associations in the European countries insuring natural perils, or whether they apply such a system.

53 Norsk Naturskadepool, Insurance against natural perils in Norway, 5th May, 1994, 3.

54 These exclusions include, inter alia, damage to forests, crops, motor vehicles, aircraft, ships and small boats, and tool used in the production of oil and gas, see Standard Conditions for natural damage insurance, in force since 1st January, 1991.

55 See Renger, F., "Verzekering en natuurrampen in Nederland", in Natuurrampen en verzekering. Verslagboek Negende Leuvense Verzekeringsdagen, COUSY, H. \& CLAASSENS, H. (ed.), Antwerp, Maklu Uitgevers, 1995, 133-149.

${ }^{56}$ Article 6, 2, e, Act 21/1990. 


\section{b. Second variant}

Another variety consist of, in most cases, mandatory pools. The individual private insurer underwrites the risk, collects the premium and is member of a common insurance pool. The main objectives of the pool is to distribute the compensation for natural damages between the member and companies and to establish reinsurance coverage for the insurance of natural perils on behalf of the members.

Such a system is usually provided for by a statute. A prominent example is the Norwegian Pool of Natural Perils ("Norsk Naturskadepool") of which each fire insurer who has the authorization to offer services in Norway must be a member. ${ }^{57}$ Also, the Swiss Natural Disaster Pool ("Schweizer Elementarschäden-Pool") for flood and landslide belongs to this group. Unlike the Norwegian Pool of Natural Perils, membership of the pool is not compulsory for insurers who insure property situated in Switzerland. 58

These systems can also be regulated by the sector itself. This is the case with the Swiss Earthquake Pool ("Interessengemeinschaft zur Übernahme von Erdbebenschäden"). ${ }^{59}$ This pool for earthquake damage to buildings is organized by and regulated by private insurers. Every member of the Swiss Association of Property Insurers is automatically a member of the Swiss Earthquake Pool. If an insurer is not a member of this association, he cannot join the Swiss Earthquake Pool. ${ }^{60}$ This pool is composed of private insurers that insure goods against fire located in the Cantons Obwalden, Genf, Uri, Schwyz, Tessin, Appenzell IR, Wallis, the Principality of Liechtenstein, Büsingen and Campione. Damage to goods which are located in the other 19 Cantons can be compensated by the Cantonal public fire insurers ("Kantonale Monopoolgebäudeversicherer"). They regulate and organize the pool for the compensation of damage to goods by natural perils like storm, flood, snowpressure, landslide. They have also set up the Swiss Pool for Earthquake Compensation ("Schweizerischen Pool für Erdbebendeckung"). Both pools offer similar coverage to as the pools of the private insurers.

\section{c. Third variant: Danish Flood Damage Board}

In Denmark, the Danish Act on Compensation of 6th June, $1991^{61}$ for damage caused by Flood, provide for the Flood Damage Board. The individual private fire insurer collects, besides the regular fire premium, an additional risk premium (an annual tax on each policy) of DKK 10 and transfers this in its entirety to the Flood Damage Board each month. ${ }^{62}$ This Flood Damage Board ensures the investment of the funds. It enjoys a limited form of

${ }^{57}$ Norsk Naturskadepool, fax of 28th October, 1994.

58 Pursuant to Article 38a, 5, b, Act of 20th March, 1992, membership of the pool can be made compulsory by Decree of the Bundesrat. The Swiss Pool for Natural Disasters has already been operating since the beginning of the fifties.

59 Reglement für die Vergütung von Erdbebenschäden of 9th June, 1980; Statut Interessengemeinschaft zur übernahme von Erdbebenschäden of 9th June, 1980.

60 Since this Earthquake Pool was set up, no compensable earthquake damage occurred.

${ }^{61}$ Articles 6-9, Act of 6th June, 1991. Until now, no claim has been made against the Danish State guarantee.

62 If the policy is taken out with a foreign insurer, it is the insured himself who is responsible for passing the premium on, on pain of losing any payment from the pool, Article 7 (3) and Article 8 (1) (3), Act of 6th June, 1991. 
state guarantee in the sum of DKK 200 million, which is recomposed by a legally fixed supplementary premium ex post (a temporary increase of the annual tax) for the reimbursement of capital and interest (see infra). Therefore, the Danish system can be defined as an insurance based on an ex ante premium collection and an ex post premium limited to reconstitution of the state guarantee. It has to be noted that this system only regulates the compensation of flood, meaning "inundation resulting from an extremely high water level of the sea caused by storm". 63

\section{d. Fourth variant: the Spanish Consorcio}

The fourth variety of the system of insurance on the basis of an ex ante premium collection is where the individual private insurer underwrites a property damage insurance policy, collects an compulsory additional risk premium on the capital insured and transfers it each month entirely to a public insurer. ${ }^{64}$ This is the system prescribed by the Spanish Act 21/1990 and Royal Decree 2022/1986 concerning the compensation of natural disasters by the "Consorcio de Compensaçion", a public insurer. ${ }^{65}$ The feature of this system is that there is no contractual obligation whatsoever between the private insurer and the insured. The policy does not describe any coverage for natural disasters. On the contrary, the damage by natural perils is automatically covered by the public insurer in all cases where the insured has a fire policy or another kind of insurance contract covering damage to goods. In case of a disaster, the public insurer has the duty to make arrangements for loss adjustment and to pay out the compensation. However, the public insurer has no direct contact with the insured; he is represented by the private insurer of the basic policy. ${ }^{66}$ Therefore, the private insurer acquires no liability. Should the Consorcio reject a claim, then the insurer cannot legally intervene and settle the claim on its behalf. This public insurer benefits from an unlimited State guarantee.

\subsection{Establishing the premium before the event}

The basic feature of the four systems described above, is the determination and payment of a defined ex ante premium before any insured event has occurred. Follows a brief summary of the methods of establishing the premium.

Except in the exceptional cases where the risk of natural disaster is standard coverage, ${ }^{67}$ the insured pays a special risk premium. In many cases, this risk premium has to be assessed separately, alongside the premium for the basic coverage ${ }^{68}$ and is reported separately in the balance sheet. ${ }^{69}$

${ }^{63}$ Article 1, (2), Act of 6th June, 1991.

64 The private insurer may deduct $5 \%$ as commission for collection, Le "Consorcio", 25 . In the event of a claim occurring under a policy where the premium charged for the fire insurance is not in accordance with the tariff, the compensation would be reduced proportionaly to whatever percentage the fire rate is below the tariff, Axco Insurance Intelligence services, Market Report on Spain, September 1995,78 .

65 The Consorcio is a State organisation with a legal status and capital of its own, and its activities are subject to the regulations of the private sector.

66 Le "Consorcio", 32-33.

${ }^{67}$ See supra, Portugal and the U.K.

68 Inter alia in Norway, Denmark and Spain.

${ }^{69}$ Inter alia in Norway, Switzerland Article 6,3 Bundesrat decree of 18 th November 1992, as amended. 
In those countries in which insurance against natural disasters is legally regulated, the premium is established by the authorities, in some circumstances following consultation with the insurers. ${ }^{70}$

In addition, it is nevertheless important to establish that the authorities, even in the absence of any specific legislation concerning natural disasters, do play a part in stipulating the amount of the premium. Such was inter alia the case in Greece for earthquake hazards. This premium was binding, except where the amount insured was greater than GDR $850,000,000^{71}$, or where the insured property is a residence. ${ }^{72}$ We heard however that the part of the tariff that was obligatory has been set free in September 1996, although at that time there was no official announcement. In Switzerland, the premium for flood and landslide (one for buildings and one for contents) is laid down by the association of property insurers on the basis of the guidelines prescribed in art. 6 of the Bundesdecree of 18th November, 1992 and is binding for all insurers.

Usually, the amount of the premium is based on a fixed percentage of the insured value. In some countries, this percentage is uniform for all policies, regardless of the property insured ${ }^{73}$ In other countries, this percentage varies depending on the nature of the insured property, ${ }^{74}$ or depending on the location of the insured property. ${ }^{75}$

The existing statutory provisions for coastal flooding in Denmark would indeed appear to be unique. The risk premium (an annual tax), was laid down by law as a fixed sum of DKK $10^{76}$ per policy per year, regardless of the insured value or the nature of the insured

70 E.g. in Norway, where the premium is adjusted annually on the basis of a proposal by the Norwegian Natural Perils Pool after approval by the authorities.

71 Approximately BEF 110.500 .000 .

72 Details obtained via the reinsurer Secura, October 1994.

73 In Norway, as from 1st July, 1993, the premium rate is $0.25 \%$ of the sum insured per annum. As from 1st January, 1980, the premium rate was $0.08 \%$; from 1st January $1983,0.10 \%$, but from 1 st January, 1990 back to $0.08 \%$; from 1st January 1991 the rate was again raised to $0.1 \%$ until 1st July, 1992 when the rate was raised to $0.17 \%$ until 1 st July 1993 when it was raised to $0.25 \%$ and on 1 st July 1995 back to $0,17 \%$. The latest reduction reflected the trend of lower reinsurance costs. See Norsk Naturskadepool, Insurance against natural perils in Norway, 5th May, 1994, 4; Vesta Forsikring, fax of 10th September 1996.

74 In Spain: the premium rate for inter alia homes and offices is $0.092 \%$ of the sum insured per annum; for commercial risks $0.18 \%$; industrial risks $0.25 \%$. This premium rate is binding on all policies, even in the case where a private insurer would coverage these natural disasters under better conditions that the minimum conditions laid down in the law; see Le "Consorcio", 24; Article 25, 1 second non-life insurance directive of 22nd June, 1988.

In Portugal, it was agreed between the most important Portuguese insurers in consultation with the major reinsurers, that the premium rate for earthquakes would as of 1th January, 1994 be fixed at $0.6 \%$ to $0.3 \%$ for buildings; for contents they apply the same tariffs $\times 50 \%$, see information obtained via reinsurer Secura, September 1994. flooding.

75 Inter alia in Greece, Germany for earthquakes, Italy, Portugal for earthquakes, the U.K. for

76 Approximately BEF 50. 
property. ${ }^{77}$ The additional ex post premium (a temporary increase of the annual tax) for reimbursement of the State guarantee (capital and interest) has likewise been laid down by law at DKK 10 per policy per year. ${ }^{78}$

\section{Relationship between the private insurer and the pool}

One of the characteristics of the above-described second and third variant of insurance on the basis of an ex ante premium collection is the organization of a mandatory pool. These pool organizations have been reviewed with regard to the management of the pool, the solidarisation of the damage and the settlement of the claims. The results of this research show that these pools are different both in purpose and operation.

On the one side, we find the Danish Flood Damage Board. On the other side, there is the Norwegian Pool of Natural Perils ("Nork Naturskadepool"), the "Schweizer Elementarschäden-Pool" (flood and landslide) and the "Swiss Interessengemeinschaft zur Übernahme von Erdbebenschäden" (earthquake). ${ }^{79}$

1. Management of the pool

The Danish Flood Damage Board consists of a chairman and seven members, all appointed by the Minister of Industry. These seven members represent the Ministry of Industry, the Ministry of Justice, the Ministry of Transport, the Danish Insurance Association, the Consumer Council, the Association of Country Councils and the National Association of Local Authorities. ${ }^{80}$ Thus, Danish fire insurers are represented on the Flood Damage Board by the Danish Insurance Association. ${ }^{81}$

On the other hand, the Norwegian and Swiss pools are only composed of and managed by the member insurers, possibly along with members of commissions of the Swiss Association of Property Insurers. ${ }^{82}$ The administration and daily management of the Norwegian pool is handled by the Norwegian Insurance Association. Likewise, the administration and daily management of the Swiss Earthquake Pool is carried out by the Swiss Association of Property Insurers. ${ }^{83}$

\section{Principle of solidarisation of loss}

In Norway, all insurers that underwrite fire insurance policies concerning property situated in that country ${ }^{84}$ are obliged to be a member of the Norwegian Pool of Natural Perils ("Norsk Naturskadepool"). Likewise, all Danish fire insurers must collected the risk premium (annual tax) and transfer the amount to the Flood Damage Board, in order to constitute the pool funds. In case the fire policy is taken out with a foreign insurer, this

77 Article 6 (3), Act of 6th June, 1991.

78 Article 9 (4), Act of 6th June, 1991.

79 The two Swiss pools of cantonal Monopolversicherer for earthquake and flooding and landslides and possible ad hoc pools that can be set up to coverage particular risks, such as e.g. pools for industrial risks in Italy are not taken into account, because of lack of sufficient information.

80 Article 10 (1), Act of 6th June, 1991.

81 Article 11 (1), Act of 6th June, 1991.

82 Clauses 12-16, Pool Contract of the Elementarschäden-Pool; Articles 7-11, Regulation Swiss Earthquake Pool.

83 Clause 11, Swiss Earthquake Pool contract.

84 Norway: see UNI STOREBRAND, fax of 23rd September, 1994. 
obligation to pass on the risk premium is incumbent upon the insured himself. ${ }^{85}$ Notwithstanding the Swiss statutory rules concerning flooding and landslide, it is not compulsory to join the Elementarschäden-Pool. However, each insurer issuing fire policies in Switzerland may become a member of this pool. ${ }^{86}$ On the other hand, those who are member of the Swiss Association of Property Insurance, are also member of the Swiss Pool for Earthquake Insurance.

Concerning the solidarity among insurers, there are quite revealing differences. They can be summarized into four major groups, depending on the private insurer's share of the total burden of loss per event.

2.1. The Danish regulation for damage caused by coastal flood can be ranged under the first group. There is no solidarity on the side of the private insurers. The insurer does not bear any risk. He must only transfer the premium, otherwise he must pay interest for late payment. The funds of the pool are placed with the Danish National Bank, for management as agreed between the Flood Damage Board and the Danish National Bank and under the supervision of the Minister of Industry and the Danish Financial Supervisory Authority. ${ }^{87}$ The Flood Damage Board invests these funds with the Danish National Bank which, with the consent of the Flood Damage Board and under governmental supervision, manages the funds. ${ }^{88}$ In the event of a claim, the compensation is paid out from the funds, thus accumulated. In the event that the funds placed in the flood at any time do not coverage the administration costs and compensations, the Minister of Industry shall be authorised, in accordance with the Danish State, to guarantee to pay up to DKK 200 million to the flood pool ${ }^{89}$ In this Danish system, the private fire insurers overall bear no risk and are not involved in compensating the loss caused by coastal flooding. Between the insured and the private insurer, there does not even exist any contractual relationship relating to coverage for coastal flooding. ${ }^{90}$

2.2. The Norwegian Pool of Natural Perils belongs to the second group. The fire insurer collects the premium and holds the money in a special reserve, which must be specified separately in the balance sheet. All the damage and costs are pooled, even though there is a limit per event. All damages covered according to the law are distributed between the member companies in proportion to the companies' portfolio in fire insurance. The total loss to be compensated per occurrence has been legally restricted since 1st January, 1994, to NOK 1,800 million. If the damage exceeds the ceiling, there will be a proportional reduction of the compensation..$^{91}$ In so far as the insurer might have undertaken other or more generous conditions than can be claimed against the pool, ${ }^{92}$ such damage should be compensated by

${ }^{85}$ Articles 7 (3) and 8 (1), (3), Act of 6th June, 1991.

${ }^{86}$ Clause 3, Pool Contract.

${ }^{87}$ Article 12, Act of 6th June, 1991.

${ }_{88}$ Article 12, Act of 6th June, 1991. million.

${ }^{89}$ Article 9, Act of 6th June, 1991. This State guarantee amounts to approximately BEF 1.000

${ }^{90}$ Danish Insurance Association, fax of 15th November, 1994.

${ }^{91}$ Norsk Naturskadepool, op. cit., 3. The limit is approximately BEF 9.000 million.

92 Since 1st July, 1992, the same conditions have applied to all pool members, Norsk Naturskadepool, fax of 28th October, 1994. 
the company concerned and may not be distributed through the pool. .93 If there is a surplus, this shall be kept in a separate fund which may only be used to compensate natural peril losses in the future. In addition to the indemnity paid, the companies are entitled to claim expenses from the pool. They can receive from the pool a lump-sum reimbursement of their management costs. These expenses are fixed to NOK 1.500 per claim for compensation up to NOK 50.000. For compensations between NOK 50.000 and NOK 200.000, the expenses are fixed at $3 \%$ of the compensation amounts and $1 \%$ of compensation amounts above NOK $200.000 .{ }^{94}$

2.3. Into the third group, we place the Swiss Earthquake Pool. The members of this pool underwrite only a building fire policy and offer no coverage for earthquake damage. The insured pays no additional premium. The damage and the management costs are pooled entirely. ${ }^{95}$ Each insurer contributes to the burden of loss in the sum of a quota calculated on the basis of the proportion between the insured buildings capital of the company and the insured building capital of all the members. ${ }^{96}$ The total loss to be compensated per event is legally limited to CHF 100 million. ${ }^{97}$

2.4. The Swiss Elementarschäden-Pool belongs to the fourth group compensating flood and landslide damages. Premiums for natural peril insurance (buildings and contents separately) are paid to each company by the policyholders together with the fire insurance premiums. The insurer does not transfer this premium onto the pool, but holds it in a separate fund. The pool takes care of reinsurance and compensation of the loss. An important feature of this pool is that it is constituted out of two distinct "Solidaritätsk reisen", one for buildings and one for contents ${ }^{98}$ For both components of the pool, the following rules apply: each member of the pool bears $15 \%$ of the losses and management costs for its insured itself; the other $85 \%$ of the losses and management costs are pooled. Each member contributes to the burden of loss in the sum of a quota calculated on the basis of the proportion between the insured fire capital of the company and the insured fire capital of all the pool members. ${ }^{99}$

The total loss to be compensated per occurrence is legally limited to CHF 150 million per event. ${ }^{100}$ If this ceiling is exceeded, the loss will be compensated on a pro rata basis. Here as well, the rule applies that the insurer bears the risk for obligations that might have been entered into above and beyond the pool arrangements.

\footnotetext{
${ }^{93}$ This applies mainly to damage by strong winds which are not storms (less than $21 \mathrm{~m} / \mathrm{sec}$.) and damage due to inrush of water not considered as inundation or flood. See Norwegian Pool of Natural Perils, fax of 6th September, 1996, 5.

94 Norse Naturskadepool, op. cit., 4.

95 Clause 4, Pool Contract.

96 Clause 5, Pool Contract.

97 This amounts to approximately BEF 2,400 million.

98 Clause 5, Pool Contract.

99 Clauses 5 and 6, Pool Contract.

100 Article 5, Bundesrat Decree of 18th November, 1992, as amended.
} 


\section{Claims settlement}

Regarding claims settlement, the Danish regulation is again a special case. Pursuant to the Danish Act of 6th June, 1991, the decision as to whether there has been a flood in an area at a given time shall be made by the Flood Damage Board after obtaining the opinion of the Danish Coast Authority. ${ }^{101}$ The policyholder shall notify his insurance company of any damage caused by flood no later than two months after the occurrence of the damage. This insurer shall assess the damage. He can designate the expert who assesses the loss. The policyholder has the right to submit any comments on this report. The insurer passes the report and the insured's comments on to the Flood Damage Board. ${ }^{102}$ The Board decides on the compensation to be awarded, notifies the policyholder of this decision and makes any payment of compensation. ${ }^{103}$ Every claim concerning an award of compensation must be filed with the Flood Damage Board, and not with the fire insurer. ${ }^{104}$ There is no appeal against this decision to any other administrative tribunal. ${ }^{105}$

In Norway, every insured files his claim with his insurer. Each company compensates its own policyholders, according to the guidelines set down by the National Pool of Natural Disasters. An injured party who is not content with the claim settlement (no compensation or reduced compensation), may lodge a complaint with the Complaint Commission of the National Natural Perils Fund. ${ }^{106}$ Similar rules apply in Switzerland. Here as well, damage from flooding and landslide is assessed and compensated by the fire insuree. ${ }^{107}$ Similarly, the pool's task is to distribute the compensation between the member companies, ${ }^{108}$ to draw up guidelines for the settlement of cases, to monitor their application ${ }^{109}$ and to rule on claims by insurers concerning decisions by the Claims Commission. ${ }^{110}$ Compensation for earthquake damage is regulated in the same way. Each insurer compensates its own insurers in accordance with the instructions and under the monitoring of the pool's Claims Commission. The only important difference between the two compensation system is that the limited compensation for earthquake damage is only granted after an explicit decision by the pool to compensate the particular event.

\section{Conclusion}

This description shows that the insurance pools in Denmark, Norway and Switzerland differ in their organization and operation.

101 Article 1 (1), Act of 6th June, 1991.

102 Article 13 (1)-(3), Act of 6th June, 1991.

103 Article 13 (4)-(5), Act of 6th June, 1991.

104 Danish Insurance Association, fax of 15th November, 1994.

105 Article 14, Act of 6th June, 1991.

106 Norsk Naturskadepool, op. cit., 4. The Standard Conditions for Natural Damage Insurance make explicit mention of this procedure, Article 2.3, Standard Conditions for Natural Damage Insurance, NAT 1-3, January 1991

107 Clause 4, Pool Contract.

108 Clause 10, Pool Contract.

109 Clause 16, Pool Contract.

110 Clause 13 and 20, Pool Contract. 
On the one side, we find the Danish rules concerning insurance against coastal flood. Contrary to the Belgian National Disaster Fund, which pays out a fixed sum to everyone. In the Danish system, the solidarity is limited to those who have taken out a fire insurance policy. Comparable to the Belgian system, there is no solidarity on the side of the insurers. The insurer does not bear any risk. He transfers the risk premium to the pool. He prepares the claims file, but does not bear any responsibility for the final decision with regard to the compensations paid out. The Flood Damage Board only uses the insurers' expertise and know-how.

On the other side, there is the Swiss insurance system for flood and landslide. This is the only system of private insurance on the basis of an ex ante premium collection which incorporates a certain solution for the moral hazard problem of the insurers who are members of the pool. Indeed, it is the only system whereby the insurer bears a part of the compensation of damage paid out to those who are insured as well as of the accompanying costs.

Finally, it should be stressed that, with the obvious exception of the Danish rules, there is no possibility to claim state guarantee in any country, in case the compensation is insufficient as a result of the insurance payments. In Norway, where the National Natural Perils Fund still exists, the insured who receives only a pro rata compensation, in case the funds of the Norwegian Pool of Natural Perils have been depleted, cannot claim an additional payment from the National Natural Perils Fund. The latter compensates damage only when the damage is not covered by insurance or if it had been possible to take out insurance against the damage by means of ordinary and common types of insurance.

\section{Evaluation of the system}

The private insurance of goods against flood, earthquake and landslide can be organized according to more than one model. In this respect, it is not without importance that information on the profitability and efficiency of these private insurance systems give for each of them a positive result. According to reports, the results of the Spanish Consorcio during the period of 1971-1991 were positive and the formula is "extrêmement satisfaisante". 111 The results for the Swiss Elementarschäden-Pool were also positive for the period 1980-1993.12 For the period of 1983-1993, a positive result was noted for the Norwegian Natural Catastrophe Fund. ${ }^{113}$

In Denmark, the Flood Damage Board has already paid out compensation on four occasions. The most serious flooding was in February 1993. In that case, nearly 1.000 files were opened and about DKK 42 million paid out. ${ }^{114}$ There has as yet been no call to lay claim against the State guarantee.

\footnotetext{
111 Le "Consorcio", 26; 34.

112 Association of Property Insurers, fax of 27th October, 1994.

113 Norsk Naturskadepool, op. cit.,5-6; Norsk Naturskadepool, fax of 28th October, 1994, 5-9.

114 Danish Insurance Association, letter of 24th August, 1994.
} 


\section{E. Conclusion}

We can conclude that damage caused by the natural perils discussed here is mostly covered by an extension of the scope of the fire coverage, either in fire policies only, either in all policies insuring damage to goods. This extension can be made mandatory by law or merely imposed by the market. Nevertheless, not one single country has opted for a compulsory fire coverage.

Apart from the application of the systems of self-insurance and government supported self-insurance with it is the system of private insurance on the basis of an ex ante premium collection that is deployed everywhere. The legally regulated systems of natural perils insurance are founded on the principle of solidarity on the side of the insured as well as on the side of the insurers, irrespective of the existence of a (mandatory) pool. An exception to this rule applies for compensation for coastal flooding in Denmark, where there is only solidarity among those who have taken out a fire policy. Albeit the Danish compensation rules for coastal flooding likewise function with the cooperation of the insurers and on the basis of a pool, this system should therefore be considered as a system of government compensation, operating on the basis of insurance principles.

\section{Insurance or solidarity compensation paid out by insurers}

The question must be raised whether the systems of private insurance which have been described above, correspond to either a traditional insurance or to a de facto solidarity compensation paid out by an insurer instead of the government. This question is particularly relevant with regard to a country such as Belgium, which wants to replace the compensation granted by the authorities without any contractual obligation with a contractually stipulated insurance payment by the insurer.

In accordance with the traditional definition of an insurance contract (e.g. defined in Article 1, A of the Belgian National Insurance Contract Act of 25th June, 1992) such agreement should have the characteristics that an insurer (A) against the payment of a fixed or variable premium, $(C)$ must render a performance defined in the agreement $(B)$ in case that an uncertain event occurs.

\section{A. In exchange for payment of a fixed or variable premium}

This prerequisite, that every policy presupposes that the insured pays a fixed or variable premium, is quite undoubtedly satisfied in the rules described herein. In this regard, reference is made to the analysis concerning the establishment of the premium payable before the event (see supra).

\section{B. In the event an uncertain event occurs}

The uncertain event that has to occur before the insurer is required to perform is the insured risk, flood, earthquake or landslide referred to. The research of the legal rules and policy conditions reveals a large degree of uncertainty about the precise nature and extent of the insured risk. Consequently, there is legal uncertainty about the uncertain event which must occur in order for the insurer to perform the agreement. Moreover, this legal 
uncertainty directly affects the insured. He bears the burden of proof as to whether or not there exists any insurance. 115

Briefly, four fundamental problems can be distinguished.

\section{Insufficient basic criteria}

First of all, this uncertainty is, in particular, the result of the absence of any definition or more precise description of the concepts "flood, earthquake and landslide". 116 Insofar as there are some more precise descriptions, the content is often very different. As a result these concepts do not have a uniform meaning in European laws and practice. It is of course a joke to gloss over the problem by suggesting that "everyone is well aware what is to be understood by these systems".

\section{Ambiguity with regard to the nature of causality}

Furthermore, a similar ambiguity exists with regard to the nature of the causality between the event (flood, earthquake, landslide) and the damage. This is in particular the case when a flood, earthquake or landslide is the cause of other natural phenomena. For example, an earthquake under the sea may cause flood or storm which are the direct cause of the damage. Such "associated phenomena" are important in the insurance of natural disasters. One has indeed to consider that the associated phenomenon (e.g. flood or storm) and the damage resulting there from, cannot be caused otherwise than by the earthquake. However, quite often the coverage against earthquake excludes damage caused by flood following an earthquake. The same happens when the damage caused by an earthquake is covered, but not the damage caused by fire following the earthquake. As a result, the insured who has earthquake and fire coverage, will nevertheless be left without compensation. Insofar as the loss caused by associated phenomena is indeed excluded, this exclusion needs in any event to be stipulated in detail and in clear and express terms.

\section{Further illustration}

To illustrate these problems further, the definition in legislative texts or policy conditions ${ }^{117}$ are stated in more detail in the following two overviews.

\subsection{Definition of the earthquake risk}

Coverage for loss by:

3.1.1. "Sacudida brusca del suelo que se propaga en todas los direcciones, producida por un movimiento de la corteza terrestre o punto mas profundo" (Spain, Article 3, Royal Decree 2022/86).

115 The most frequent causes of the complaint concern the definition "storm" and "flood" and the question of reduced compensation due to faulty or insufficient construction, Norsk Naturskadepool, op. cit., 4.

116 In Greece, the Association of Insurance Companies is making an effort to introduce definitions in the insurance policies regarding earthquake, flood and landslide, although they will not be compulsory to insurers.

117 In order to avoid inaccuracies in translation, it has been decided as possible to quote the clauses in their original languages as far. We regret that we received only the Norwegian Standard Conditions for Natural Damage Insurance of January 1991, the Norwegian Industrial Insurance Terms of March 1994, the British Recommended Standard Fire and Special Perils Policy for commercial and industrial risks, the Swiss fire insurance policies and the general conditions under a Belgian policy. 
3.1.2. "Erdbeben ist eine naturbedingte Erschütterung des Erdbodens, die durch geophysikalische Vorgänge im Erdinnern ausgelöst wird.

Erdbeben wird unterstellt, wenn der Versicherungsnehmer nachweist, daß

a) die naturbedingte Erschütterung der Erdbodens in der Umgebung des Versicherungsortes, Schäden an Gebäuden in einwandfreiem Zustand oder an ebenso widerstandfähigen anderen Sachen angerichtet hat, oder

b) der Schaden wegen des einwandfreien Zustandes des Gebäudes, in dem sich die versicherten Sachen befunden haben, nur durch ein Erdbeben entstanden sein kann." (Germany, Bedingungen BEH; BEW; BEG).

3.1.3. a) earthquake with an intensity of at least VII on the Mercalli scale ( $=5$ to 6 on the Richter scale). (Switzerland, Article 1.2, Swiss Pool of Insurance of Earthquake Rules).

b) earthquake (i.e. the entire phenomena linked to the distortion of the earth's crust) the strength of which reaches at least 4 on the Richter scale. (Belgium, a fire policy, covering fire and related dangers).

c) earthquake with an intensity of at least 4 on the Richter scale. (Netherlands, proposal on insurance by a pool of the government and private insurers).

d) any officially acknowledged and registered earthquake that has reached a magnitude of at least 4 on the Richter scale and, within a radius of $10 \mathrm{~km}$ of the insured property affected, has also destroyed or damaged other property. The earthquake and the aftershocks therefrom, within 72 hours, shall be regarded as one single occurrence.

Besides this, damage from ground swell or flood that is caused by the earthquake shall be excluded.

(Belgium, BVVO-CASO proposal).

e) is caused by an earthquake, tidal wave, or flood that is the consequence thereof. Earthquake is understood to mean the movement of the earth's crust that, according to the Royal Meteorological Institute has a strength of at least 4.5 on the Richter scale.

(Belgium, a fire policy for home/fire policy for offices and buildings, earthquake coverage).

3.1.4. earthquake

or

earthquake, except for fire damage or fire damage caused by an earthquake

(U.K., Recommended Standard Fire and Special Perils Policy, May 1991).

\subsection{Definition of the risk of flood}

Coverage the damage by:

3.2.1. Inundation from an extremely high water level of the sea caused by storm.

(Denmark, Article 1, Act of 6th June, 1991).

3.2.2. "Elementarschäden sind Schäden, die durch die Elementarereignisse Hochwasser, Überschwemmung (...) entstehen.

Keine Elementarschäden sind:

a) Schäden verursacht durch (...) Grundwasser, Ansteigen und Überborden von Gewässern, die sich erfahrungsgemäß in kürzeren oder längeren Zwischenräumen wiederholen; 
b) ohne Rücksicht auf ihre Ursache Schäden, die entstehen durch Wasser aus Stauseen oder sonstigen künstlichen Wasseranlagen, Rückstau von Wasser aus der Kanalisation;

c) (...)".

Under the coverage water damage is also insured:

"Rückstau aus der Abwasserkanalisation und Grundwasser im Innern des Gebäudes".

(Switzerland, Bundesratdecree of 18th November, 1992; policy for Versicherung von Gebäuden, Geschäftsbetrieben, Hausrat gegen Feuer-, Wasser- und Glasbruchschäden).

3.2.3. "Überschwemmung ist eine Überflutung des Grund und Bodens, auf dem das versicherte Gebäude liegt oder in dem sich die versicherten Sachen befinden, durch

a) Ausuferung von oberirdischen (stehenden oder fliessenden) Gewässern

b) Witterungsniederschläge.

Nicht versichert sind ohne Rücksicht auf mitwirkende Ursachen Schäden durch

a) Sturmflut

b) Rückstau".

(Germany, Bedingungen BEH; BEW; BEG).

3.2.4. "Inundación: la producida por acción directa de la aguas de fluvia, la procedente de deshielo, o la de los lagos, que tengan salida natural, de los ríos, o de cursos naturales de agua en superficie, cuando éstos se desbordan de sus cauces normales, o por los embates de mar en las costas (inter alia run off of water from rain, overflowing of the sea, lakes, rivers, dashing of the sea against the land).

No serán compensables los daños producidos por aguas procedentes de prensas, canales, alcantarillas, colectores y otros cauces subterráneos, construidos por el hombre, al reventarse, romperse o averiarse por hechos que no correspondan a riesgos de carácter extraordinario amparados por el Consorcio de Compensación de Seguros (inter alia bursting of dams, conduits of drains, leakage, landslide, subsidence)". (Spain, Article 3 Royal Decree 2022/86).

3.2.5. "- where lakes, ponds, watercourses burst their banks as a result of rising water or of atmospheric precipitation, the breaking of dykes and ground swell.

- the overflow or impoundment of the public sewers as a consequence of rising water or atmospheric precipitation.

Overflows that occur over a single period of 72 hours shall be regarded as a single occurrence. Exclusions: the content of cellar stories and damage caused by subterranean water ingress." (Belgium, BVVO-CASO Proposal).

3.2.6. Tidal water (sea): no coverage. Non-tidal water (fresh): coverage does apply.

For fresh water from river areas, a difference is drawn between the embanked and nonembanked river areas.

For the non-embanked river area (Meuse Valley from Maastricht to Mook/Cuyk): compensation covers exclusively the area where the measured water level of the Meuse exceeds certain levels.

For the embanked river area: property outside the dyked area (such as foreland) is not covered. (Netherlands, pool proposal).

\subsection{7. "M. Storm excluding}

a) damage by inundation from the sea, whether resulting from storm or otherwise 
b) damage attributable solely to change in the water table level.

"N. Storm or flood excluding

a) damage attributable solely to change in the water table level"

"P. Escape of water from any tank apparatus or pipe excluding

b) damage in respect of any building which is empty or not in use"

"S. Accidental escape of water from any automatic sprinkler installation in the premises not caused by

b) earthquake"

(U.K., Recommended Standard Fire and Special Perils Policy, May 1991).

3.2.8. "All direct and indirect damage to the insured property caused by flood, overflow or high water level of water courses, whether or not canalized is covered, in so far as these are of unforeseeable and exceptional strengh".

"Exclusion: damage caused by flood, overflow or high water level to buildings (and their contents) that are situated at a distance of less than $200 \mathrm{~m}$ from the Meuse, the Schelde, the Ijzer, the Semois, the Lesse, the Samber or any water course whathever of comparable proportions, or on ground that is regularly under water, as also damage comprising the fact that the cellars of the building are regularly under water."

(Belgium, policy, coverage for Miscellaneous damage).

\section{Additional problems}

The condition in an insurance contract that an uncertain event must occur, often creates yet another additional problem in the case of insuring against natural perils. Indeed, sometimes it is not only necessary that the uncertain event of "flood, earthquake or landslide" described in the policy should occur. This uncertain event must in addition still be recognized as a "disaster" in accordance with criteria about which the insured is at best inadequately informed. ${ }^{118}$ This official recognition of a natural force as being a natural disaster is a necessary condition for coverage in France ${ }^{119}$ and in the Belgian BVVO-CASO proposal with regard to earthquakes. ${ }^{120}$

These are, to our knowledge, the only regulations imposing the condition of an official recognition of the exceptional character of a natural force before the insurance policy will be triggered. ${ }^{121}$ It seems that this is only a prerequisite in those systems in which the private

118 Such recognition as a "catastrophe" must be distinguished from the provisions in which it is provided that information will be obtained from independent sources in order to establish whether an uncertain event stipulated in the contract has occurred. E.g. the provision in Clause 1.2 Pool Contract Swiss Earthquake Pool, that the intensity of the earthquake is determined on the basis of the data from the Swiss Seismological Service in Zurich.

119 By ministerial order.

120 See also the current condition of a recognition by Royal Decree after consultation with cabinet for payment by the Belgian Disasters Fund, Article 2, § 2, Act of 12th July, 1976. Also in the Belgian insurers proposal (BVVO-CASO), it is assumed that the Belgian Disasters Fund will continue to intervene.

121 France, Article L 125-1, al. 3 Code des Assurances "intensité anormale"; Belgium, Article 2, § $1,1^{\circ}$, Act of 12 th July 1976 "the natural phenomena of an exceptional nature or such force as could not be foreseen, that have caused serious damage". 
insurance is combined with some form or another of state support. Nevertheless, it is not an indispensable condition for the intervention of the authorities, given that this is not prescribed in Spain. One might wonder whether imposing such a requirement as a necessary condition for the intervention of the insurer does not affect the balance between the contractual rights and obligations of the parties under an insurance policy. Moreover, is it not for the very reason that the damage by natural forces is always a disaster for the insured himself, regardless of the extraordinary characteristic of the natural phenomenon and the extent of the overall damage that he takes out an insurance policy?

\section{Performance due by the insurer}

Before one can speak of an insurance policy, a third prerequisite must be fulfilled, comprising the fact that the insurer has to render a certain performance defined in the policy. As far as the compensation which the insurer has to provide is concerned, it is undoubtedly the special nature of those risks that justifies limitations on the coverage. Nevertheless, it is necessary that the insurance coverage is in accordance with the damage. In addition, the insured must, at the time of the agreement, at least know the criteria on the basis of which the damage will be assessed, in order to have a clear indication of the amount of the possible compensation. If these conditions are not fulfilled, it is with difficulty that one can still speak of an insurance policy.

In the special case of the Swiss rules for compensation of earthquake damage to buildings, these conditions are not met. Indeed, this coverage is not provided for in the insurance policy. The insured does not pay a risk premium for earthquake and the rules of the Pool for Insurance of Earthquake state explicitly that there is no entitlement to such a payment.

In addition, the data available reveals several important general principal themes. However, an in-depth analysis of this problem falls outside the scope of this study and, cannot be developed in the absence of adequate policy conditions. Important aspects which are not further discussed include inter alia, the exclusions, calculation of compensation on the basis of replacement value or actual value, and the obligation with respect to reconstruction.

\section{Overview tables}

Limit per occurrence: earthquake (under reservation of altered figures)

Legal rules

\begin{tabular}{|l|c|c|c|c|c|}
\hline & Excess & Policy & Company & Sector & State \\
\hline Norway & NOK & $\begin{array}{c}\text { sum } \\
\text { insured } \\
\text { basic } \\
\text { cover }\end{array}$ & $\begin{array}{c}\text { pool } \\
\text { quota }\end{array}$ & $\begin{array}{c}\text { NOK } \\
1.800 \text { million }\end{array}$ & - \\
\hline Spain & $10-15 \%$ & $\begin{array}{c}\text { \% sum } \\
\text { insured } \\
\text { of loss } \\
\text { max. } 1 \%\end{array}$ & - & - & maximum \\
& min. ESP & cover & & & \\
& 25.000 & - & & & \\
\hline
\end{tabular}

- non-existent 
Limit per occurrence: earthquake (under reservation of altered figures)

Policy practice

\begin{tabular}{|l|c|c|c|c|c|}
\hline & Excess & Policy & Company & Sector & State \\
\hline $\begin{array}{l}\text { Switzerland } \\
\text { buildings }\end{array}$ & $\begin{array}{c}10 \% \text { of damage } \\
\text { min. CHF 5.000 }\end{array}$ & CHF 500.000 & pool quota & $\begin{array}{c}\text { CHF } \\
100 \\
\text { million }\end{array}$ & \\
\hline Greece & $1,5-2 \%$ of sum insured & & - & - & - \\
\hline Germany & $\quad 10 \%$ & & - & - & - \\
\hline Italy & $\begin{array}{c}\text { ANIA recommendation } \\
0.20 \% \text { of sum insured } \\
\text { min.ITL } 10 \text { million } \\
\text { max. ITL100 million }\end{array}$ & & - & - & - \\
\hline $\begin{array}{l}\text { Portugal: } \\
\text { buildings } \\
\text { contents }\end{array}$ & $\begin{array}{c}2 \% \text { of sum insured } \\
2 \% \text { of sum insured } \times 50 \%\end{array}$ & & - & - & - \\
\hline Sweden & $10 \%$ min. SEK 10.000 & & - & - & - \\
\hline
\end{tabular}

- non-existent

Limit per occurrence: flooding (under reservation of altered figures)

Legal rules

\begin{tabular}{|c|c|c|c|c|c|}
\hline & Excess & Policy & Company & Sector & State \\
\hline Denmark & DKK 5.000-10.000 & & - & - & DKK 200 million \\
\hline Norway & NOK 4.000 & $\begin{array}{l}\text { sum insured } \\
\text { basic cover }\end{array}$ & pool quota & $\begin{array}{c}\text { NOK } \\
1.800 \\
\text { million }\end{array}$ & - \\
\hline $\begin{array}{l}\text { Switzerland: } \\
\text { Hausrat } \\
\text { other contents } \\
\text { buildings }\end{array}$ & $\begin{array}{c}\text { CHF } 200 \\
10 \% \text { of damage } \\
\text { min. CHF } 500 \\
\text { max. CHF } 10.000 \\
10 \% \text { of damage } \\
\text { min.CHF } 200 \\
\text { max. CHF } 10.000\end{array}$ & $\begin{array}{l}\text { CHF } 10 \\
\text { million }\end{array}$ & pool quota & $\begin{array}{c}\text { CHF } \\
150 \\
\text { million }\end{array}$ & - \\
\hline Spain & $\begin{array}{c}10 \%-15 \% \text { of } \\
\text { damage } \\
\text { min. } 1 \% \text { sum insured } \\
\text { max. ESP } 25.000\end{array}$ & $\begin{array}{c}\% \text { sum insured } \\
\text { basic cover }\end{array}$ & - & - & maximum \\
\hline
\end{tabular}

- non-existent 
Limit per occurrence: flooding (under reservation of altered figures)

Policy practice

\begin{tabular}{|l|c|c|c|c|c|}
\hline & Excess & Policy & Company & Sector & State \\
\hline Greece & $1,5 \%-2 \%$ of sum insured & & - & - & - \\
\hline Germany & $10 \%$ & & & - & - \\
\hline Italy & $\begin{array}{c}\text { ANIA recommendation: } \\
0.2 \% \text { of sum insured } \\
\text { min. ITL } 10 \text { million } \\
\text { max. ITL } 100 \text { million }\end{array}$ & & - & - & - \\
\hline Sweden & $\begin{array}{c}\text { min. } 10 \% \\
\text { SEK } 10.000\end{array}$ & & & & \\
\hline
\end{tabular}

- non-existent

\section{Clarification}

In this overview of a number of primary themes of the compensation to be paid out by the insurer, a distinction is drawn between the market conditions, the legally imposed (minimum) conditions and the insurance conditions that are stipulated on the basis of the guidelines edited by the pool.

\subsection{Excess}

All the legal rules, as well as general practice, impose an excess. This excess is mostly expressed as a fixed percentage of the insured value, often with a minimum and a maximum. In Norway, the excess is legally fixed at NOK 4.000 per event. ${ }^{122}$ In Denmark, the excess amounts to between DKK 5.000 and 10.000 per event per place, depending on the property insured. ${ }^{123}$

\subsection{Limit per sector}

A maximum payment for all companies together per event is only to be found in the rules of the Norwegian and Swiss pools. In Norway, the limitation per occurrence of natural damage is now fixed at NOK 1.800 million. ${ }^{24}$ The maximum intervention for flooding and landslide in Switzerland is CHF 150 million per event and, for earthquakes, at present CHF 100 million. ${ }^{125}$

122 Currently, this is approximately BEF 20.000 .

${ }^{123}$ Article 4, Act of 6th June, 1991. This is currently approximately BEF 25.000 to 50.000 .

${ }^{124}$ It is well possible that the Norwegian Natural Perils Pool will advise the authorities to increase the limit to NOK 2.800 million or possibly NOK 3.000 million from 1th July, 1997, Vesta Forsikring, fax of 10th September, 1996.

${ }^{125}$ Bundesrat Decree, art. 5, 1 of 18th November, 1992 as amended. The limit of the Swiss Pool for Insurance of Earthquake is among CHF 500 million. 


\subsection{Limit per insurance policy}

Stipulating a maximum compensation per policy per event appears to be somewhat exceptional. According to our information, this limit only appears in Switzerland, where it is statutory fixed at CHF 10 million for flooding and landslide ${ }^{126}$ and CHF 500.000 for earthquakes. ${ }^{127}$ In general, the compensation appears to be in relation to the sum insured for the basic cover. ${ }^{128}$

\section{Concluding remarks}

Within the scope of this overview of private insurance against damage to goods by flood, earthquake and landslide in some European countries, various aspects of such insurance could not be discussed. In some countries, some of these problems are already addressed, but in general there is not much information available. Among the most serious problems are, in no particular sequential order:

1. the necessity and possibility of the tax regime of the reserves. Although this problem is talked about internally in various countries, ${ }^{129}$ it has a clear Community law dimension;

2. the regime of the commission on the risk premium for insurance intermediaries (and, in some cases, supplementary contributions);

3. what happens when the fire coverage has to include compensation for natural disasters, but the fire insurer refuses to conclude a fire policy. Albeit the insurer might refuse to conclude the policy owing to the hazard of natural perils, the insured will have no fire coverage, even though that risk presents absolutely no problem of insurability; 130

4. the transparency of the different arrangements;

5. the average time to settle a claim;

6. the prevention by the government; ${ }^{131}$

126 Article 5, Bundesrat Decree of 18th November, 1992.

127 Clause 3.4, Pool Contract. The Austrian insurer that provided information limits flood and earthquake cover in each case to ATS 50.000 per event, both for buildings and for contents, and a maximum of ATS 200.000 .000 for all damages attributable to the same atmospheric or tectonic cause.

128 E.g. in Norway, see VESTA, fax of 7th October, 1994; Spain, see Le "Consorcio", 16.

${ }^{129}$ E.g. in the U.K., where insurers cherish the hope that next year the insurance market will be in a state to constitute a disaster reserve, free of tax, see British Insurers' International Committee, letter of 30th August, 1994. See for Portugal, Administrative ruling no. 1076/93 of 27th October, 1993.

130 Under French law, this is a task conferred onto the Bureau Central de Tarification. Cf. problems when one wants to take out fire insurance for objects usually not exposed to fire, mainly to obtain insurance against natural perils.

131 Article 11 (4), Danish Act of 6th June,1991 stipulates that to promote preventive action the Flood Damage Board may issue directions to the injured party, and make proposals to the public authorities for such action as the Board shall deem necessary to minimize the consequences of flood. In the U.K. the Environment Agency (formerly National Rivers Authority) has since 1994 done a lot of work on flood warning/risk assessment. In Portugal, the government has since many years insisted on a form of building code. A proper seismic code was adopted in 1958 and subsequently amended. 
7. the efficient linkage of prevention and insurance by means of reduction or exclusion of compensation; 132

8. the functioning of the various national markets and regulations within the European Internal Market.

An efficient private insurance of natural disasters obviously requires a solution for these problems as well as a global approach. Nevertheless, the lack of effective solutions for these problems should not be invoked as an obstacle to tackling the problem of private insurance of damage to goods caused by flood, earthquake and lanslide.

Private insurance against the hazards discussed here in technical insurance policies and motor hull policies is not questionned. Moreover, it is clearly shown that private insurance against these natural perils does actually exist and can be organized along the lines of more than one model. Thereby, it is not without importance that both the Norwegian and Swiss pools themselves acknowledge that their systems work efficiently.

We hope that this study of the law and practice of insurance against natural disasters in some European countries, offers several interesting approaches that could lead to a balanced, effective regulation, organizing a reasonable priced insurance for damage to goods caused by flood, earthquake and landslide. Private insurance does belong to the curative technique of risk management. The time and conditions call for a regulation. Will it be the next disaster that compels to find a solution? Or maybe the competition within the European Internal Market?

132 In the Danish and Norwegian Acts and policy conditions, it is stipulated that inter alia compensation for damage may be reduced or not payable if building requirements are not adhered to, when the injured party is aware of or expects a particularly large risk of damage, or has failed before or after the occurrence of the damage to take reasonable action to prevent or minimize the damage. 